\title{
Contribution of antiretroviral therapy, cardiovascular risk factors and constituents of metabolic syndrome to insulin resistance(IR) in HIV
}

\author{
M Cervero Jiménez*, R Torres Perea, JL Agud Aparicio, JJ Jusdado Ruiz- \\ Capillas, C García Lacalle, M del Álamo Rodríguez and E García Benaya
}

Address: H. Severo Ochoa, Leganés. Madrid, Spain

* Corresponding author

from Ninth International Congress on Drug Therapy in HIV Infection

Glasgow, UK. 9-13 November 2008

Published: 10 November 2008

Journal of the International AIDS Society 2008, I I (SuppI I):PI00 doi:I0.II86/I758-2652-I I-SI-PI 00

This abstract is available from: http://www.jiasociety.org/content/I I/SI/PI00

(c) 2008 Jiménez et al; licensee BioMed Central Ltd.

\section{Purpose of the study}

To assess the association between antiretroviral therapy, cardiovascular risk factors and constituents of metabolic syndrome to IR.

\section{Methods}

We studied all patients who had a visit in our outpatient HIV clinic during 2007. The following data were collected: age at diagnosis of HIV infection, gender, country of origin, smoking status, HCV co-infection, HIV risk group, AIDS diagnosis, CD4+ cell count, HIV viral load, fasting glucose and insulin levels, lipid profile, blood pressure, waist circumference, BMI and present HAART. We used the HOMA index to assess insulin resistance, choosing as cut-off point 3.8. The IDF criteria have been used to define increased waist circumference, hypertension, hypertrygliceridemia, low HDL cholesterol and hyperglycemia. We assessed the association of these variables with IR using a multivariate logistic regression predictive model. Blood glucose value was not taken into account in the analysis since it is embedded in the HOMA index. Discriminating power of the model was analyzed by means of a receiver operating curve (ROC). The effect measure was the adjusted odds-ratio with $95 \%$ confidence interval (CI).

\section{Summary of results}

128 patients were analyzed. Median HOMA index was 2.12 (IQR 1.26-3.39). 75\% were males and median age was 43 years (IQR 39-46). Viral load was below 50 copies in $78 \%$ and median CD4+ count was $397 \mathrm{cel} / \mathrm{microL}$. Only $8.6 \%$ were immigrants. The most prevalent HIV risk group was intravenous drug use (IDU) (57.8\%). 25\% had an AIDS diagnosis and HCV co-infection rate was $64.1 \%$. Metabolic syndrome, as defined by IDF criteria, was present in $29.6 \%$. Moreover, $74.2 \%$ were smokers. $49 \%$ were taking PI, $34.4 \%$ NNRTI and $16.4 \%$ NRTI. Hypertension (OR 2.92, 95\% CI 1.04-8.22, P = 0.042), hypertriglyceridemia (OR 2,88, 95\% CI 1,01-8,19, $\mathrm{P}=0.047$ ), increased waist circumference (OR 8,33, 95\% CI 2,53$27,5, \mathrm{P}=0.0001$ ) and smoking (OR 3.56, 95\% CI 1.03$12.38, \mathrm{P}=0.046)$ were associated with an increased risk of IR. HCV co-infection and HAART were not associated with IR. The model showed a high predictive power (AUC 0.79, 95\% CI 0.69-0.88, $\mathrm{P}=0.0001$ ).

\section{Conclusion}

1. Patients with HIV infection in our cohort had a higher prevalence of metabolic syndrome than the prevalence in the Spanish population (19.3\% according to WHO); 2 . These patients have an increased cardiovascular risk due to high smoking rate; 3 . The four factors associated with IR in HIV patients are hypertension, increased waist circumference, hypertrigliceridemia and smoking. 


\section{References}

I. Marrugat J, et al.: Coronary risk estimation in Spain using a calibrated Framingham function. Rev Esp Cardiol 2003, 56(3):253-6I.

Publish with Bio Med Central and every scientist can read your work free of charge

"BioMed Central will be the most significant development for disseminating the results of biomedical research in our lifetime. " Sir Paul Nurse, Cancer Research UK

Your research papers will be:

- available free of charge to the entire biomedical community

- peer reviewed and published immediately upon acceptance

- cited in PubMed and archived on PubMed Central

- yours - you keep the copyright

Submit your manuscript here:

http://www.biomedcentral.com/info/publishing_adv.asp 